\title{
Regioselective Synthesis of Tetrasubstituted Olefins via an Alkenyl Catellani Reaction
}

Metals in Synthesis

\section{Key words}

Catellani reaction palladium catalysis

$\mathrm{C}-\mathrm{H}$

functionalization<smiles>[R]CCCC1=C(CC=CC(C)=O)CCN(C(=O)OC(C)(C)C)C1</smiles>

$62 \%$ yield
$\mathrm{Pd}(\mathrm{cod}) \mathrm{Cl}_{2}, \mathrm{~N} 11$ (50 mol\%)

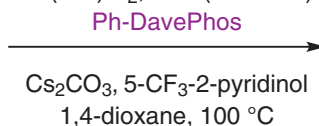<smiles>[R]C=CC1=C([2H])CC[Te]C1</smiles>

45 examples up to $92 \%$ yield<smiles>CNC(=O)C1=CC2CCC1C2</smiles><smiles>CN(C)c1ccccc1-c1ccccc1</smiles>

$\mathrm{Ph}$-DavePhos<smiles>CCCCC(CCc1ccccn1)=C(CCCC)COCCC</smiles>

$46 \%$ yield
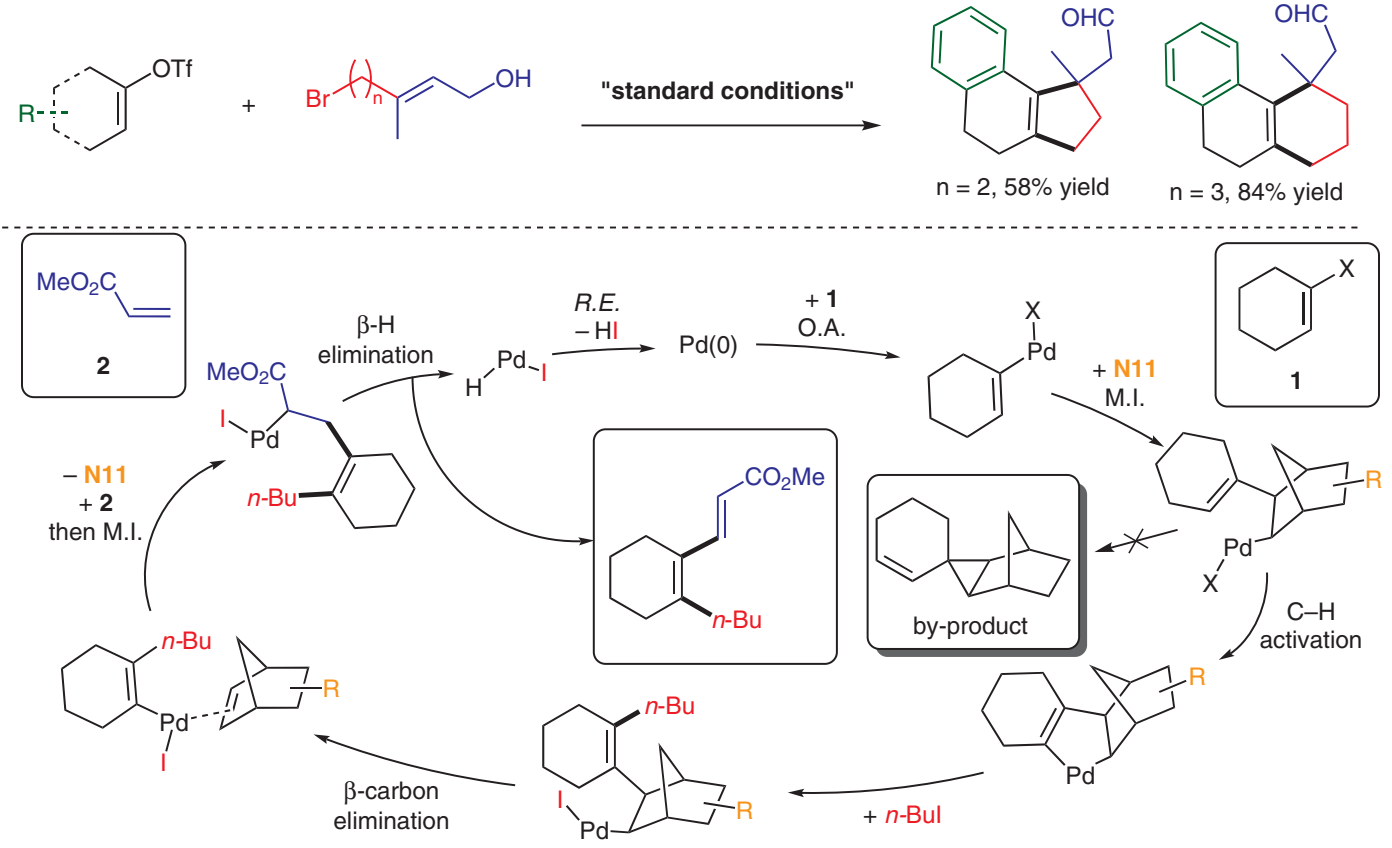

Significance: The Dong group reports a general method for the bis-functionalization of alkenes via a Catellani reaction. This method affords unsymmetrical tetrasubstituted alkenes. The use of a functionalized norbornene gave high yields and selectivities.
Comment: Utilization of the $\mathrm{N}$-methyl amide-substituted norbornene (N11) was optimal as it gave the highest yield of product and eliminated the formation of the cyclopropane adduct. A mechanism was proposed that was supported with detailed kinetic analysis. 